\title{
Recombinant biosynthesis of functional human growth hormone and coagulation factor IX in transgenic soybean seeds
}

\author{
Nicolau Brito da Cunha*, André Murad, Giovanni Vianna, Elíbio Rech \\ From 5th Congress of the Brazilian Biotechnology Society (SBBIOTEC) \\ Florianópolis, Brazil. 10-14 November 2013
}

\section{Background}

Plants constitute promising systems for the alternative production of valuable recombinant proteins. Recently, ELELYSO $^{\text {TM }}$, an enzymatic drug developed by the Israeli company Protalix Biotherapeutics to treat Type 1 Gaucher's disease, became the first plant-derived therapeutic product to reach marketable status [1]. This confirms the inherent potential of plant systems for the large-scale production of pharmaceuticals and industrial proteins with high quality and at competitive costs. Soybeans [Glycine max (L.) Merrill] provide a potential economically viable platform for the large-scale production of different therapeutic molecules. Plant seeds are specialized in the stable accumulation of proteins at high levels, representing an excellent source of abundant and cheap biomass. Additionally, the vegetative growth of plants can be significantly extended under a daily photoperiod of $23 \mathrm{~h}$ of light, inducing more than a tenfold increase in seed production when compared with plants cultivated under field conditions [2]. In this report we present the recombinant biosynthesis and the molecular and functional characterization of two important therapeutic proteins in transgenic soybean seeds: the $22 \mathrm{kDa}$ human growth hormone (hGH) and the $56 \mathrm{kDa}$ human coagulation factor IX (hFIX), a vitamin K-dependent serine-protease glycoprotein utilized to treat Type B Christmas disease, the second most frequent haemophilia variant $[3,4]$.

\section{Methods}

A biolistic process was used to introduce the plasmids p $\beta$ cong3hGH (4,786 bp) and pbcong3FIX (5,406 bp), respectively carrying the $h g h$ and $h F I X$ coding sequences under the transcriptional control of the alpha prime $\left(\alpha^{\prime}\right)$ subunit of $\beta$-conglycinin tissue-specific promoter from Glycine $\max (\mathrm{L}$.) Merrill and the $\alpha$-Coixin signal peptide from Coix lacryma-jobi, in soybean embryonic axes from mature seeds (cv. BR-16). Independent transgenic lines were analyzed by PCR and characterized by Southern blot. The transcription levels of the correspondent coding sequences were evaluated by RT-PCR of immature seeds and the accumulation of the proteins in the protein storage vacuoles (PSVs) of the seeds was detected by Western Blot and ultrastructural immunocytochemistry assays. Partial N-terminal sequencing of both proteins was determined by nano-Lc mass spectrometry assay. The biological activities of the molecules were evaluated by somatogenic activity bioassay (for the hGH), and by activated partial thromboplastin time assay (for the hFIX).

\section{Results}

Expression levels of bioactive hGH and hFIX were, respectively, of up to $2.9 \%$ of total soluble seed protein content (corresponding to approximately $9 \mathrm{~g} \mathrm{~kg}^{-1}$ ) and up to $0.23 \%\left(0.8 \mathrm{~g} \mathrm{Kg}^{-1}\right)$. Immunocytochemistry assays indicated that both molecules were efficiently directed to protein storage vacuoles in seed cotyledonary cell. The recombinant hGH and hFIX protein sequences were confirmed by mass spectrometry characterization and showed no post-translational modifications on the spectra covered by the assays. The somatogenic activity bioassay demonstrated that the hGH expressed in soybean seeds is fully active. Protein extracts from transgenic seeds containing the hFIX showed a blood-clotting activity of up to $1.4 \%$ of normal plasma. 


\section{Conclusionsand perspectives}

Soybean seeds seem to be promising vehicles for the stable accumulation of the recombinant hGH and hFIX, once it was possible to detect biologically active molecules in grains stored up to six years at room temperature.

Published: 1 October 2014

\section{References}

1. Paul MJ, Teh AY, Twyman RM, Ma JK: Target product selection - where can Molecular Pharming make the difference? Curr Pharm Des 2013, 13:5478-5485.

2. Vianna GR, Cunha NB, Murad AM, Rech EL: Soybeans as bioreactors for biopharmaceuticals and industrial proteins. Genet Mol Res 2011, 10:1733-1752.

3. Cunha NB, Murad AM, Cipriano TM, Araújo AC, Aragão FJ, Leite A, Vianna GR, McPhee TR, Souza GH, Waters MJ, Rech EL: Expression of functional recombinant human growth hormone in transgenic soybean seeds. Transgenic Res 2011, 20:811-826.

4. Cunha NB, Murad AM, Ramos GL, Maranhão AQ, Brígido MM, Araújo AC, Lacorte C, Aragão FJ, Covas DT, Fontes AM, Souza GH, Vianna GR, Rech EL: Accumulation of functional recombinant human coagulation factor IX in transgenic soybean seeds. Transgenic Res 2011, 20:841-855.

doi:10.1186/1753-6561-8-S4-P112

Cite this article as: da Cunha et al:: Recombinant biosynthesis of functional human growth hormone and coagulation factor IX in transgenic soybean seeds. BMC Proceedings 2014 8(Suppl 4):P112.

\section{Submit your next manuscript to BioMed Central} and take full advantage of:

- Convenient online submission

- Thorough peer review

- No space constraints or color figure charges

- Immediate publication on acceptance

- Inclusion in PubMed, CAS, Scopus and Google Scholar

- Research which is freely available for redistribution

Submit your manuscript at www.biomedcentral.com/submit 